\title{
RIVERINE CATFISHES OF KALIMANTAN, PANGASIIDAE: DIAGNOSIS, DISTRIBUTION, AND ECOLOGY
}

\author{
Rudhy Gustiano") and Laurent Pouyaud")
}

\begin{abstract}
The main constrain to cultivate wild species and optimize the production of cultured species is to due poorly documented of genetic resources. In the current study, it presents the diversity of pangasiids catfishes from Kalimantan. Nine hundreds and ninety nine specimens formed the core of the material examined during this study. On each specimen, 35 point to point measurement, covering the possible variation of the body conformation were taken using dial calipers. Data were subjected to principal component analysis. Data analysis consisted in characterizing groups from scatter plots between pairs of structuring characters for subsequent use in generic identification keys. Three genera with fourteen species exist in eigth main rivers, Barito; Kahayan; Kapuas; Batang Rajang; Kinabatangan; Kayan; Berau, and Mahakam. They are Helicophagus typus, Pteropangasius micronemus, Pangasius polyuranodon, $P$. kunyit, $P$. djambal, $P$. macronema, $P$. nasutus, $P$. lithostoma, $P$. humeralis, $P$. kinabatangensis, $P$. sabahensis, $P$. rheophilus, $P$. nieuwenhuisii, and $P$. mahakamensis. The diagnosis of the species, identification key, distribution, and
ecology are given.
\end{abstract}

KEYWORDS: diversity, Pangasiidae, catfish, Kalimantan

\section{INTRODUCTION}

The family of the Pangasiidae belongs to the suborder Siluroidei, order Siluriformes, and superorder Ostariophysi (Fink \& Fink, 1981; Nelson, 1994; Teugels, 1996). In general, Pangasiids are riverine catfishes generally occurring in freshwater from the Indian subcontinent to the Indonesian Archipelago. As a consequence of human activities and heavy exploitation, many species in this family are presently being threatened with extinction. The World Conservation Union (IUCN) already lists some species as endangered. Thus, the extraordinary diversity and distribution pattern of the Pangasiidae based on a long evolutionary process is now being rapidly modified under human threats.

In the Mekong Delta, the aquaculture production of Pangasius significantly exceeds the production from capture fisheries, showing the economical importance of their aquaculture in the global fisheries sector. Meanwhile, in Indonesia, although more than 10 Pangasiid species have been listed, the only Pangasius cultured remained Pangasianodon hypophthalmus, introduced from Thailand (Legendre, 1999). Of the 14 valid species from Kalimantan, few have been reproduced successfully: Pangasius nasutus, $P$. nieuwenhuisii, and $P$. djambal. Objectives of the study are to present all species and genera of pangasiid catfishes of Kalimantan including their distribution and ecology for aquaculture purposes.

\section{MATERIALS AND METHODS}

Nine hundred and ninety nine specimens, collected during the "Catfish Asia" project (Legendre, 1999), formed the core of the material examined during this

\footnotetext{
Research Institute For Freshwater Aquaculture (BRPBAT)
}

'Institute de Recherches pour le Developpement (IRD) study. On each specimen, 35 point to point measurements covering the possible variation of the body confirmation were taken using dial calipers as follows: standard length (SL) from tip of snout to caudal peduncle; head length $(\mathrm{HL})$ from tip of snout to posterior border of operculum; snout length (SNL) from tip of snout to anterior eye border; anterior snout width (SNW1) taken between the anterior nostrils; the posterior snout width (SNW2) taken between posterior nostrils; head depth (HD) taken at the level of the posterior eye border; head width (HW) inter-orbita length taken on frontal part of the head; predorsal distance (PDL) from tip of snout to base of first dorsal spine; caudal peduncle length (CPL) from base of last anal fin ray to middle of caudal peduncle; caudal peduncle depth (CPD) taken as minimum body depth; pectoral spine length (PESL) from its base to its tip; pectoral fin length (PEFL) from pectoral spine base to tip of fin; dorsal spine length (DSP) from base of first dorsal spine to tip; dorsal fin length (DFL) from base of first dorsal spine to tip of fin; pelvic fin length (PFL) from base to tip of fin; anal fin height $(A F H)$ from base of first anal fin ray to tip of longest ray; anal fin length $(A F L)$ from base of first ray to base of last anal ray; adipose fin height (ADFH) from base to tip; maximal adipose fin width (ADFW); maximal orbital diameter (ED); mouth width (WM); lower jaw length (LJL) from tip of snout to corner of mouth; interorbital distance (WT) taken between the eyes; distance snout to isthmus (DSI) from tip of snout to isthmus with a closed mouth; postocular length (OL) from posterior border of eye to posterior border of operculum; maxillary barbel length (MBL); mandibular barbel length (MABL); body width (BW) from left to right scapular excrescence bones close to pectoral spine base; prepectoral length (PPEL) from tip of snout to pectoral spine base; prepelvic length (PPL) from tip of snout to first pelvic fin ray base; vomerine width 
$(\mathrm{VMW})$; vomerine length (VML); palatine length (PAL); palatine width (PAW); dorsal spine width (DSW) taken at base of second dorsal spine. The following meristic counts were noted: number of gill rakers on the first branchial arch, number of dorsal, pelvic, pectoral, and anal fin rays. An illustration of the measured characters is shown in Pouyaud et al., (1999), except for SNW1 and SNW2

\section{Species Characterization}

Data were subjected to principal component analysis (PCA) (Bookstein et al., 1985) using the CSS Statistica package (Stat Soft, Inc.), version 4.5 in order to define structuring characters. For this purpose, measurements were log-transformed in order to minimise the effect of non-normality before the PCA was run on the covariance matrix. The first factor, considered as the size-factor was not taken into account, in order to minimise the effect of size differences between the samples. Allometry is indicated by unequal loadings of variable on the first component, and biological interpretation of allometric data proceed using coefficients of the first components against the second components that was linear. Missing data were casewise deleted. An independent PCA was run on the correlation matrix from the untransformed count data. Finally, data analysis consisted in characterising groups from scatter plots between pairs of structuring characters for subsequent use in generic identification keys

\section{RESULTS AND DISCUSSION}

Fourteen species exist in eight main rivers in Sumatra (Table 1). Based on the analysis of 35 measured and five counted characters, the diagnosis of the species, the identification key of the species and the description are given below.

\section{Key to Genera}

1a. Slender anterior part of snout $(<16.5 \% \mathrm{HL})$, posterior nostrils are in between anterior nostrils and orbit Helicophagus.

1b. Robust anterior part of snout (>16.5\% $\mathrm{HL}$ ), posterior nostrils close behind anterior ones and above imaginary line from anterior nostrils and orbit 2.

2a. Eye relatively large, minute maxillary barbel (<192\% ED), dorsal and pectoral fins relatively thin, pectoral fin with minute and numerous serrations on the anterior and posterior edge of the fin, and minute adipose fin Pteropangasius.

$2 \mathrm{~b}$. Eye varies from small to large, relatively long maxillary barbel (>192\% ED), dorsal and pectoral fins robust, and adipose fin relatively robust Pangasius

Below, the different genera of pangasiid catfishes of Indonesia are presented. For each genus, a key to the species is given. This is followed by a detailed description for each species recognised as valid.

\section{Helicophagus Bleeker, 1858}

Diagnosis: this genus differs from all other pangasiid genera by a short and a large premaxillary toothplate; a narrow mouth $(<35 \% \mathrm{HL})$; the front border of the snout is pierced by anterior nostrils; a slender anterior part of snout length $(<16.5 \% \mathrm{HL}) ;$ a short and a large premaxillary toothplate; the posterior nostrils are between and in line with the anterior nostrils and the middle of eye; the vomerine toothplate without additional toothplate.

Table 1. The distribution of fourteen species per river: bold refers to endemic species; ${ }^{\star}$ numbers for the river and basin indicate the areas on Figure 1

\begin{tabular}{|c|c|}
\hline River and area* & Species \\
\hline Barito (1) & $\begin{array}{l}\text { Pteropangasius micronemus, Pangasius nasutus, Pangasius polyuranodon, } \\
\text { Pangasius djambal, Pangasius macronema, Pangasius. kunyit, Helicophagus } \\
\text { typus }\end{array}$ \\
\hline Kahayan (2) & Pangasius nasutus \\
\hline Kapuas (3) & $\begin{array}{l}\text { Pteropangasius micronemus, Pangasius nasutus, Pangasius polyuranodon. } \\
\text { Pangasius kunyit, Pangasius lithostoma, Pangasius humeralis, } \\
\text { Helicophagus typus }\end{array}$ \\
\hline Batang Rajang (4) & Pteropangasius micronemus, Pangasius nasutus and Pangasius polyuranodon \\
\hline Kinabatangan (5) & $\begin{array}{l}\text { Pteropangasius micronemus, Pangasius polyuranodon, } \\
\text { kinabatanganensis, and Pangasius sabahensis }\end{array}$ \\
\hline Kayan (6) and Berau (7) & Pangasius rheophilus \\
\hline Mahakam (8) & $\begin{array}{l}\text { Pteropangasius micronemus, Pangasius kunyit, Pangasius nieuwenhuisii, } \\
\text { and Pangasius mahakamensis }\end{array}$ \\
\hline
\end{tabular}




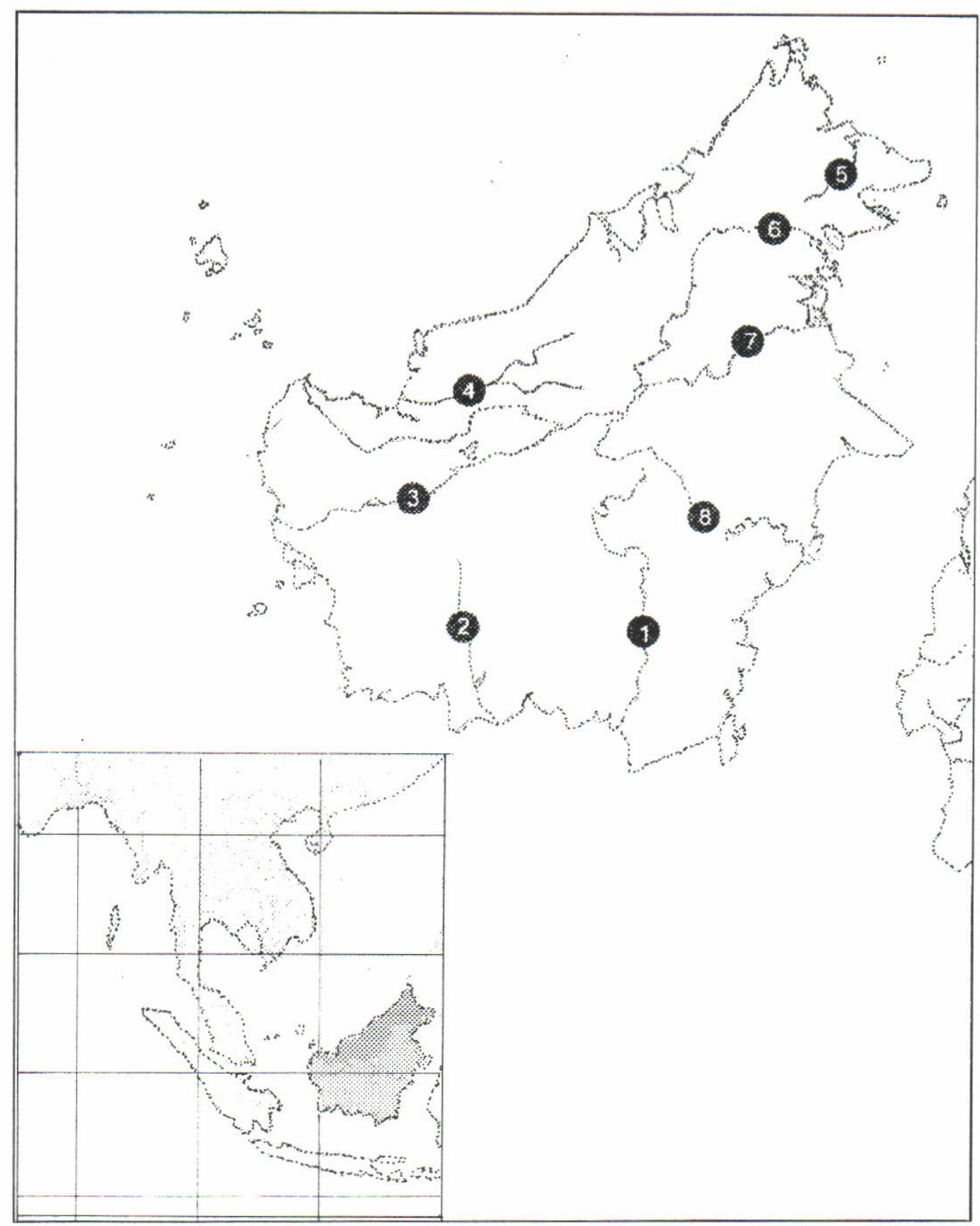

Figure 1.

The major rivers of Kalimantan: 1. Barito; 2. Kahayan; 3. Kapuas; 4. Batang Rajang; 5 Kinabatangan; 6. Kayan; 7. Berau; 8. Mahakam.

\section{Key to Species}

Anal rays 27-30; premaxillary teeth in a single curved band; gill rakers on the first branchial arch 27 33; eye diameter less than $9.3-13.5 \% \mathrm{HL}$; mandibular barbel less than $35 \%$; anal fin length less than $32.9 \%$; Helicophagus typus.

\section{Helicophagus typus Bleeker, 1858a}

Diagnosis: anal rays 27-30; premaxillary teeth in a single curved band; gill rakers on the first branchial arch 27-33; mandibular barbel less than 35\% $\mathrm{HL}$; eye diameter $9.3-13.5 \% \mathrm{HL}$; anterior part of snout width $14.7-16.5 \% \mathrm{HL}$; anal fin length $29-32.9 \% \mathrm{SL}$; body width $14.4-17.2 \%$ SL; prepelvic length $41.6-48.3 \%$ SL. 
Distribution. Helicophagus typus occurs in the major Kalimantan drainages: Kapuas River, Sintang, West Kalimantan; Barito River, Muara Teweh, Central Kalimantan. This species occurs in the middle to upper part of the river basins.

Ecology: this species is molluscivorous. The holotype had the stomach entirely filled with hundreds of small gastropods (Bleeker, 1858b). The stomach of the specimen from west Kalimantan was entirely filled with small clams identified as the bivalve Potamocorbula sp (Musikasinthorn et al., 1998). The gut contents of four specimens obtained from Sumatra were examined and gastropods as well as bivalves were found in the gut ( $T$ an $\& \mathrm{Ng}, 2000$ ). In the present study, one specimen from the Musi River had only tubificid worms in the stomach.

\section{Pteropangasius Fowler, 1937}

Diagnosis: this genus is distinguished from other genera by minute maxillary barbels ( $<192 \%$ ED), dorsal and pectoral fin relatively thin, pectoral fin with numerous minute serrations on the anterior and posterior edge of the spine, minute adipose fin, and eye relatively large.

\section{Key to Species}

Predorsal length $28.1-37.7 \%$ SL; anal fin length $22.8-35.2 \%$ SL; anal fin rays $26-40$; additional toothplates of vomerine toothplate completely separated from vomerine toothplate Pteropangasius micronemus.

\section{Pteropangasius micronemus (Bleeker, 1847)}

Diagnosis: predorsal length 28.1-37.7\% SL; prepectoral length $15.4-22.6 \% \mathrm{SL}$; anal fin rays $26-39$; additional toothplate of vomerine toothplate completely separated from vomerine toothplate; eye diameter $15.5-37 \% \mathrm{HL}$.

Distribution: Pangasius micronemus occurs in major drainages in Kalimantan in the Batang Rajang, Kinabatangan, Kapuas, Barito, Mahakam Rivers.

Ecology: the author revealed that Pangasius micronemus is detritivore. In the gut content. I found dung, debris, head of schrimp insect wing, and fragment of small bones. They live in the middle to upper part of rivers in the shallow part.

\section{Pangasius valenciennes, 1840}

Diagnosis: six pelvic fin rays, short predorsal length $(<37 \%)$, and robust dorsal spine width $(>5 \% \mathrm{HL})$, robust anterior part of snout length $(>16.5 \% \mathrm{HL}$ ), posterior nostrils close behind anterior ones and above imaginary line from anterior nostril and orbit, long and slender premaxillary toothplate, eye varies from small to large, relatively long barbel length (>192\% ED), dorsal and pectoral fin robust, and adipose fin relatively robust.

\section{Key to Species}

1a. Vomerine toothplate without additional toothplate 2 .

1b. Vomerine toothplate with additional toothplate 5

2a. High adipose fin (5-6\% SL) and narrow anterior part of snout width $(22.7-27.2 \% \mathrm{HL})$ Pangasius kinabatangensis

2b. Low adipose fin (less than 5\% SL) and large anterior part of snout width $(25.5-35.5 \% \mathrm{HL}) 3$.

3a. Anal fin length more than $31 \% \mathrm{SL}$ and prepelvic length less than $44 \% \mathrm{SL} P$. lithostoma.

3b. Anal fin length less than $31 \% \mathrm{SL}$ and prepelvic length $42-52.9 \%$ SL 3 .

4a.Dorsal spine width more than $7.7-9.3 \% \mathrm{HL}$ and head width more than $14.1-15.6 \%$ SL $P$. humeralis.

$4 \mathrm{~b}$. Dorsal spine width $5.5-7.6 \% \mathrm{HL}$ and head width 13.8-16.4\% SL P. nieuwenhuisii.

5a. Maxillary barbel length 100.5-203.9\% HL mandibular barbel $76.8-176.5 \% \mathrm{HL}$, and eye diameter $21.9-45 \%$ HL P. macronema.

5 b. Maxillary barbel less than $100.5 \% \mathrm{HL}$ and mandibular less than $76.8 \% \mathrm{HL} 6$.

6a.Predorsal length $25.1-31.2 \% \mathrm{SL}$ and eye diameter 16. $0-30.3 \%$ HL P. polyuranodon.

6b. Predorsal length more than $30.1 \%$ SL 7

7a. Eye diameter less than $22.8 \% \mathrm{HL}$ and predorsal length more than $31.8 \%$ SL 8 .

7b. Eye diameter 22.8-29.4\% HL and predorsal length $30.1-32.7 \%$ SL P. mahakamensis

8 a. Short distance snout isthmus (less than $110 \%$ SNL) 9

$8 \mathrm{~b}$.Long distance snout isthmus (more than $110 \%$ SNL) 10

9a. Maxillary barbel length $79-97 \%$; mandibular length $56-66 \% \mathrm{HL}$ and dorsal spine width $4.4-5.7 \% \mathrm{HL} P$. sabahensis.

9b. Gill rakers on the first branchial arch 24-32 $P$. kunyit.

10a.Dorsal spine width 4.7-6.2\% HL, head length 19.6-23.2\% SL, head width $11-14.2 \% \mathrm{SL}$, and body width $14.9-17 \%$ SL $P$. rheophilus.

10b.Dorsal spine width $5.4-10.4 \% \mathrm{HL}$, head length 21.3-28.8\% SL, head width $11.9-20.6 \%$ SL, body width $16.5-21.4 \%$ SL 11

11a.27-39 gill rakers on the first branchial arch, anterior part of snout width 29.3-36.6.5\% HL $P$. djambal

11b. Lower gill raker number on the first branchial arch (less than 27), width of mouth $41.9-52.5 \% \mathrm{HL}$, vomerine toothplate width $21.9-30.7 \% \mathrm{HL}$, and lower jaw length $23.9-31.5 \%$ HL $P$. nasutus.

\section{Pangasius kinabatanganensis Roberts \& Vidthayanon, 1991}

Diagnosis: Pangasius kinabatanganensis is distinguished by the combination of the following characters: single, very big vomerine toothplate, narrow anterior part of snout width (22.7-27.2\% HL), mouth subterminal and large $37.6-42.2 \% \mathrm{HL}$, adipose 
fin big (its height 5-6\% SL), anal fin length short 22.5 $25.5 \%$ SL with $26-31$ fin rays.

Distribution: Pangasius kinabatanganensis is endemic to the Kinabatangan River in North Borneo (present Sabah), draining into the Sulu Sea, and flowing through flat alluvial plains with a few scattered, low hill (see Inger \& Chin, 1962)

Ecology: In the present study, the guts content of five specimens were examined and hard seeds as well as small crustaceans were found in the gut.

\section{Pangasius lithostoma Roberts, 1989}

Diagnosis: Pangasius lithostoma is distinguished by the following characters: vomerine toothplate single, large and projects downwards from the roof of mouth, small adipose fin (height 2.5-4.3\% SL), prepelvic fin $40.1-43.3 \% \mathrm{HL}$, anal fin length $32.4-$ $36.4 \%$ SL with $36-41$ rays, snout oval and rounded, mouth subinferior; humeral process exposed, extending to slightly less than half way to end of pectoral spine.

Distribution: Pangasius lithostoma is only known from middle part of Kapuas, the biggest river in West Kalimantan. Kapuas River is the largest and probably has the richest ichthyofauna of any of the modern rivers derived from the Sunda drainage (Roberts, 1989).

\section{Pangasius humeralis Roberts, 1989}

Diagnosis: Pangasius humeralis is distinguished by the following characters: single enlarged vomerine toothplate, width three times in its length, narrower than other endemic species from Kalimantan, length of humeral process reaches two-third of pectoral spine length, dorsal spine robust $7.7-9.3 \% \mathrm{HL}$, compared to the other endemic species, head width $14.1-15.6 \%$ SL

Distribution: Pangasius humeralis only occurs in the middle part of the Kapuas in West Kalimantan [see $P$. lithostoma part for explanation]. This species occurs sympatrically with $P$ lithostoma (Roberts, 1989, pers obs). The local people differentiate between this species and $P$ lithostoma based on body colouration. They cail $P$ humeralis 'black seladang and $P$. lithosoma as white seladang

\section{Pangasius nieuwenhuisii (Popta, 1904)}

\section{Diagnosis: Pangasius nieuwenhuisii is} distinguished by the combination of the following characters: vomerine toothplate single and relatively wide, head robust (width 13.8-16.4\% SL; length 21.9$24.6 \% \mathrm{SL}$; depth $9.6-12.2 \% \mathrm{SL}$ ), dorsal spine width $5.5-7.6 \% \mathrm{HL}$, snout ovally rounded, eye not visible from above, humeral process extend beyond middle of pectoral spine.
Distribution: Pangasius nieuwenhuisii is endemic to Kalimantan Timur (Indonesia) and only occurs in the Mahakam basin. The Mahakam River is the second largest river in Kalimantan, with a course of some $920 \mathrm{~km}$ and a drainage area of $77.700 \mathrm{~km}^{2}$ (Christensen, 1992).

Ecology: the stomach of the holotype contains very hard seeds or higher plants, larger seed crushed some $9 \mathrm{~mm}$ intact (Roberts \& Vidthayanon, 1991). In the present study, the author found hard seeds in the gut content. When the author and fisherman did fishing, we used banana to catch the fish from the middle part of river.

\section{Pangasius macronema Bleeker, 1851}

Diagnosis: eye large $(21.9-52 \% \mathrm{HL})$, maxillary barbel very long reaching the tip of pectoral fin, mandibular barbel $76.8-176.5 \% \mathrm{HL}$, maxillary barbel always reaching pectoral fin base (100.5-203.9\% HL), gill rakers elongated and slender, $27-46$ on the first branchial arch.

Distribution: from all drainages in the Sundaic region, only a single fresh specimen was caught in our study from Barito River, Banjarmasin, Kalimantan Selatan, Indonesia. Of all specimens recorded in literature, two were from Java (Eschmeyer et al. 1998).

Ecology: this species is omnivorous, feeding mainly on insect and small fruits. Scavenger feeding habit is also found (Vidthayanon, 1993).

\section{Pangasius polyuranodon Bleeker, 1852}

Diagnosis: recognised by the unique combination of the following characters: somewhat elongated body with a short predorsal length (25.1-31.4\% SL), short head length (16.1-20.9\% SL), mandibular barbel length (62.8-236.6\% ED), eye diameter relatively big $(16-30.3 \% \mathrm{HL})$, a long caudal peduncle $(17.2-21.8 \%$ $\mathrm{SL})$, and anal rays $33-42$.

Distribution: Pangasius is present in southern and western Kalimantan, where it was found in the Barito River (same as type collection from Bleeker), in the Kapuas River and in the Batang Rajang River (Sarawak, Malaysia). The species was also recorded from North Borneo (Sabah, Malaysia) in the Kinabatangan River (Inger \& Chin, 1962) but no specimens were available for the present study.

Ecology: this species is omnivorous with a tendency to opportunism. In this study, the gut of seven specimens observed contain small gastropods, bivalves, insects, leaves, and detritus. Mature males and females of about $200 \mathrm{~mm} \mathrm{SL}$ were caught at night in October 1996 along the banks of the Musi River at Sekayu. Pangasius polyuranodon inhabits estuaries and lower reaches but it has also been observed in upper reaches during the rainy season. 
Pangasius mahakamensis Pouyaud, Gustiano \& Teugels, 2002

Diagnosis: Pangasius mahakamensis is distinguished by the unique combination of following characters: short caudal peduncle (14.0-16.7\% SL); relatively large eye diameter (22.8-29.4\% HL); mandibular barbel length (85.9-141.8\% ED); short head length (20.2-24.5\% HL); predorsal length (30.1$32.7 \% \mathrm{SL}$ ) and anal rays $27-32$.

Distribution: Pangasius mahakamensis is endemic to East Kalimantan, (Indonesia) and it is presently only known from the type locality, the Mahakam River. The Mahakam River is the second largest river in Kalimantan, with a course of some $920 \mathrm{~km}$ and a drainage area of $77.700 \mathrm{~km}^{2}$ (Christensen, 1992). Specimens smaller than $150 \mathrm{~mm}$ were collected in brackish water in the delta of the river, while larger sized specimens were found in the upper part. Both environments have no vegetation on the banks, have a relatively strong current, are deep and the water is transparent.

Ecology: the species is omnivorous, feeding mainly on insects and small fruits (Pouyaud et al., 2002).

\section{Pangasius sabahensis Gustiano, Teugels \& Pouyaud, 2003}

Diagnosis: Pangasius sabahensis is distinguished by the combination of the following characters: the short distance from snout to isthmus (90.9-102.8\% $\mathrm{SNL})$, the long mandibular $(56.0-66.0 \% \mathrm{HL})$ and maxillary barbels $(70-97 \% \mathrm{HL})$ reaching beyond the posterior border of operculum, the slender dorsal spine (width 4.4-5.7\% HL), a broad and rounded head (snout length $44.2-49.6 \% \mathrm{HL}$; head depth $11.8-14.0 \%$ SL; head width $15.2-18.3 \% \mathrm{SL}$ ), the posterior margin of the dorsal spine with $14-20$ strong serrae; the pectoral spine with $16-19$ strong serrae on the posterior margin, the short additional toothplates (6.4$10 \% \mathrm{HL})$, and $19-23$ gill rakers on the first branchial arch.

Distribution: Pangasius sabahensis is endemic to northern Borneo and is presently known only from the type locality, the Kinabatangan River, Sabah State, Malaysia This species is reported from estuarine areas.

Ecology the species is omnivorous with a tendency towards piscivory increasing with age. $P$. sabahensis occurs sympatrically with $P$ micronemus and $P$. kinabatanganensis in the Kinabatangan River (Gustiano et al., 2003).

\section{Pangasius kunyit Pouyaud, Teugels \& Legendre,
1999}

Diagnosis: Pangasius kunyit is distinguished by the combination of the following characters: the short distance between snout and isthmus (78.5-96.1\% $\mathrm{SNL}$ ), a somewhat spatulate (broad and rounded) head with a projected snout (head length $21.2-25.4 \%$ SL, head width: $15.7-18.9 \% \mathrm{SL}$, head depth $10.3-$ $13.4 \% \mathrm{SL}$, snout length $45.9-53.9 \% \mathrm{HL})$, a robust dorsal spine (width: 6.6-9.3\% HL), up to 44 strong serrae on the posterior margin of the dorsal spine, more than 40 strong serrae on posterior margin of the pectoral spine, the short additional toothplates (6.9$14.0 \% \mathrm{HL}$ ), and $24-32$ gill rakers on the complete first branchial arch.

Distribution: Pangasius kunyit is known from most of the major drainages in Kalimantan where it was found in the Kapuas River (Pontianak, Kalimantan Barat, Indonesia), in the Barito River (Kuala Kapuas and Banjarmasin, Kalimantan Tengah, Indonesia), in the Mahakam River (Samarinda and Sangasanga, Kalimantan Timur, Indonesia).

Ecology: Marine invertebrates were found in gut contents of specimens caught in the delta of the Mahakam River. This species is also piscivorous. In all environments it lives in deeper waters. The species has been collected in fresh and brackish water. Fishermen even report it from plume waters beyond the estuaries (Pouyaud et al., 1999).

\section{Pangasius rheophilus Pouyaud \& Teugels, 2000}

Diagnosis: Pangasius rheophilus is distinguished by the combination of the body width (14.9-17.0\% SL), head length (19.6-23.2\% SL), head width (11-14.2\% $\mathrm{SL})$, dorsal spine width $(4.7-6.2 \% \mathrm{HL})$ and predorsal length $(34.6-36.1 \% \mathrm{SL})$. The species is also characterised by a large rectangular vomerine toothplate bordered by long and slender palatine tooth plates. The two-chambered swimbladder is confined to the abdomen.

Distribution: Pangasius rheophilus is presently known from Kayan and Berau River in the Bulungan Regency, Kalimantan Timur (Indonesia). Pangasius rheophilus has been collected from freshwater near the mouth but also from the upper reaches of the two basins. In the lower reaches, the habitats consist of large pools near the sea, with deep and turbid waters. In the upper reaches, the habitats consist of big torrent characterized by turbulent and clear water (altitude 200-400 m).

Ecology: information from fishermen indicates that immature specimens occur all over the basin; mature specimens seem only present in the upper reaches in running water. Still according to local fishermen, the large specimens are able to cross important water falls by jumping out of the water. Mature fish were caught in November, at the beginning of the rainy season, in the upstream part of the Bahau River (Kayan tributary). Reproductive behaviour is unknown. Skeletal parts of small cyprinid species and remains of fruits were collected in the stomach of a large 
specimen (775 $\mathrm{mm} \mathrm{SL}$ ); molluscs predominant in stomach contents of small specimens (Pouyaud \& Teugels, 2000).

\section{Pangasius djambal Bleeker, 1846}

Diagnosis: Pangasius djambal is distinguished by unique combination of the following characters: 27-39 gill rakers on the first branchial arch, anterior part of snout width $29.3-36.6 \% \mathrm{HL}$, head length $21.8-27.1 \%$ SL, head width $13.4-19.4 \%$ SL.

Distribution: Pangasius djambal occurs in Kalimantan, in the Barito, Mendawai, and Kahayan Rivers.

Ecology: in the present study, the gut content of six specimens of Pangasius djambal was examined. The results showed one specimen only contained gastropods; 3 specimens contained gastropods and clams; 1 specimen contained gastropods and seeds. Based on this observation, $P$. djambal is molluscivorous with tendency to opportunism. Specimens in this study were collected from the middle to the upper part of rivers. In all environments, it lives in deeper waters. The environments have a relatively strong current. Nowadays, $P$. djambal already breeds artificially in hatcheries (Legendre et al. 2000)

\section{Pangasius nasutus (Bleeker, 1863)}

Diagnosis: Pangasius nasutus is distinguished by having an inferior mouth, with snout strongly projecting, tooth band of upper jaw entirely exposed when jaws are closed, the jaw teeth very sharp and projected, eye very small $(6.6-13 \% \mathrm{HL})$, head robust (length $22.8-28.8 \%$ SL; width $13-17.2 \%$ SL), caudal peduncle slender (depth 5.8-8\% SL), body width 16.9$21.7 \% \mathrm{SL}$, predorsal length $36.1-40.8 \% \mathrm{SL}$, gill rakers on the first branchial arch 16-24.

Distribution: Pangasius nasutus occurs in Kalimantan, in the Kapuas, Barito, Batang Rajang Rivers.

Ecology and reproduction: this species tend to be omnivorous, feeding on benthic organisms, hard seed or higher plants, and fishes (pers obs.). At present, Pangasius nasutus has an important commercial value in Sundaic region, where its capture is highly appreciated by fishermen. It is considered as a candidate for aquaculture and its reproduction in captivity has already been achieved (Legendre, 2000 : p. 23,61$)$

\section{CONCLUSION}

Principal component analysis using biometric measurements enable to distinguish three genera with fourteen species exist in eigth main rivers (Barito,
Kahayan, Kapuas, Batang Rajang, Kinabatangan, Kayan, Berau, and Mahakam) in Kalimantan. They are Helicophagus typus, Pteropangasius micronemus, Pangasius macronema, $P$. polyuranodon, $P$ kunyit, $P$. djambal, $P$. nasutus, $P$. kinabatangensis, $P$ mahakamensis, $P$. sabahensis, $P$. lithostoma, $P$ humeralis, $P$. niuewenhuisii, and $P$. rheophilus

\section{ACKNOWLEDGEMENT}

The author thanks J. Slembrouck, M. Legendre, L. Sudarto, W. Hadie, D. Sadili, O. Komarudin for their help in collecting fish samples. Special thanks due to G. Teugels for their encouragement to the present study. This paper forms part of the INCO.DC PROJECT "Catfish Asia" financed by the European Union (contract IC 18-CT 96-0043). I am also grateful to AARD for the fellowship to complete this study through 'PAATP' Project at KULEUVEN, Belgium.

\section{REFERENCES}

Bleeker, P. 1847. Nieuwe bijdrage tot de kennis der Siluroiden van Java. Verh. Batav. Genootsch. 21 . $1-12$.

Bleeker, P. 1858a. Ichthyologiae Arcipelagi Indici Prodromus. Vol. I. Siluri. Lange \& Co., Batavia, Nederland-Ind. $370 \mathrm{p}$.

Bleeker, P. 1858b. Zesde bijdrage tot de kennis der vischfauna van Sumatra. Visschen van Padang, Troessan, Priaman, Sibogha en Palembang. Act. Soc. Sci. Indo-neerl. 3: 1-50.

Bleeker, P. 1862a. Atlas ichthyologique des Indes Orientales Néerlandaises, publié sous le auspices du Gouvernement colonial néerlandais. II. Siluroides, Chacoïdes et Heterobranchoïdes. 112 p. pls. 49-101

Bleeker, P. 1862b. Notice sur les generes Parasilurus, Eutropiichtys, Pseudeutropius et Pseudopangasius. Versl. Akad. Amsterdam 14 390-399

Bleeker, P. 1863. Description de trois espèces nouvelles de Siluroïdes de I'Inde archipélagique. Versl. Akad. Amsterdam, 15: 70-76.

Bookstein, F.L., B. Chernoff, R. Elder, J. Humphries, G. Smith, \& R. Strauss. 1985. Morphometrics in evolutionary biology. The geometry of size and shape change, with examples from fishes. Acad. Nat. Sci., Philad., Spec. Publ. 15: 1-277

Christensen, M.S. 1992. Investigation on the ecology and fish fauna of the Mahakam River in the East Kalimantan, Indonesia. IntI Revue Ges Hydrobiol. 77: 593-608 
Cuvier, G. \& A. Vallenciennes. 1840. Histoire naturelle des poissons. Vol. 15. Strasbourg, French. 540 p.

Day, F 1889. The fauna of British India, including Ceylon and Burma. Fishes Vol. I (Ed. W.T. Blanford). Thacker, Spink \& Co, Calcutta, India. $548 \mathrm{p}$.

Eschmeyer, W.N., C.J. Ferraris, M. D. Hoang, \& D.J. Long. 1998. Part I. Species of Fishes. In: Catalog of Fishes (Editor: W.N. Eschmeyer). California Academy of Science, San Fransisco, USA. p: $25-$ 1820.

FAO. 2003. Review of the state of world aquaculture. FAO Fisheries Circular 886, Rome. 95 p.

Fink, S.V. \& W. L. Fink. 1981. Interrelationships of the ostariophysan fishes (Teleostei). Zool. Lin. Soc. 72: $297-353$

Fowler, HE 1937. Zoological results of the third de Schauensee Siamese Expedition, Part 8. Fishes obtained in 1936. Proc. Acad. Nat. Sci. Philad. 89 125-264

Gustiano, R., G. Teugels, \& L. Pouyaud. 2003 Revision of the Pangasius kunyit catfish complex, with description of two new species from SouthEast Asia (Siluriformes, Pangasiidae). J. Nat. Hist. 37: $357-376$

Inger, R.F. \& P.K. Chin. 1962. The fresh-water fishes of North Borneo. Fieldiena Zool. 45: 1-268.

Legendre, M. 1999. The catfish Asia project: Backgrounds, aims and prospects. In: The biological diversity and aquaculture of Clariid and Pangasiid Catfish in Southeast Asia. Proc. midterm workshop of the "Catfish Asia project" (Editors M Legendre and A. Pariselle), IRD, Paris. p. $7-14$

Legendre, M. L. Pouyaud, J. Slembrouck, R Gustiano, A.H Kristanto, J. Subagja, O Komarudin, Sudarto \& Maskur. 2000. Pangasius djambal: A new candidate species for fish culture in Indonesia. IARD Journal 22: 1-14

Legendre, M. 2000. Final Report Characterization and maintenance of biological diversity for the diversification and sustainability of catfish culture in South-East Asia. INCO-DC project "Catfish Asia" financed by European Commission (contract IC 18-CT 96-0043). $140 \mathrm{p}$.

Musikasinthorn, P., K. Utsugi, \& K. Watanabe. 1998 Rediscovery of the Pangasiid catfish Helicophagus typus in Borneo. Nat. Bull. Siam. Soc. 46: 197-201.

Nelson, J.S. 1994. Fishes of the world. John Wiley \& Sons Inc, NY, USA. $600 \mathrm{p}$

Pouyaud, L., G.G. Teugels, \& M. Legendre. 1999 Description of a new pangasiid catfish from SouthEast Asia (Siluriformes). Cybium 23:247-258.

Pouyaud, L \& G.G. Teugels. 2000. Description of a new pangasiid catfish from East Kalimantan, Indonesia. Ichthyol. Explor. Freshwater 11: 193200

Pouyaud, L., G.G. Teugels, R. Gustiano, \& M Legendre. 2000. Contribution to phylogeny of pangasiid catfishes based on allozymes and mitochondrial DNA. J. Fish Biol. 56: 1509-1538

Pouyaud, L., R. Gustiano, \& G.G. Teugels. 2002. Systematic revision of Pangasius polyuranodon complex (Siluriformes, Pangasiidae) with description two new species. Cybium 26: 243-252.

Roberts, T.R. 1989. The freshwater fishes of Western Borneo (Kalimantan Barat, Indonesia). Mem. Cal. Sci. 14: 1-210.

Roberts, T.R \& C. Vidthayanon. 1991. Systematic revision of the Asian catfish family Pangasiidae, with biological observation and description of three new species. Proc. Acad. Nat. Sci. Philad 143: 97 144.

Tan, H.H. \& Ng. H.H. 2000. The catfishes (Teleostei: Siluriformes) of Central Sumatra: J. Nat. Hist. 34 267-303

Teugels, G.G. 1996. Taxonomy, phylogeny and biogeography of catfishes (Ostariophysi, Siluroidei): An overview. Aquat. Living Resour. 9: 9-34 